ресурсів для розвитку цієї сфери, належного фінансування та розвитку інфраструктури.

\title{
Література:
}

1. Закон України «Про курорти». URL: zakon.rada.gov.ua/go/ 2026-14.

2. Більче-Золотецька обласна фізіотерапевтична лікарня URL: http://www.bzlik.te.ua/index.php/ua/

3. Гусятинська водолікарня URL: http://hata.te.ua/2018/12/04/zazdorov-iam-u-husiatyn/

4. Питуляк М.Р. Природні рекреаційні ресурси Тернопільщини, проблеми їх раціонального використання та охорони. Навч. посібник /М.Р.Питуляк. - Тернопіль, 1999. - 60 с.

5. Питуляк М.Р., Питуляк М.В. Санаторно-курортна сфера та лікувально-оздоровчий туризм. Географія Тернопільської області: монографія. В 2-х томах. Т. 2. Населення господарство. Тернопіль: Осадца Ю.В., 2020. С. 424-431

DOI https://doi.org/10.30525/978-9934-26-111-4-40

\section{ЗАЛІЗНИЧНИЙ ТРАНСПОРТ ЯК ВАЖЛИВА СКЛАДОВА ТУРИСТИЧНОЇ ІНФРАСТРУКТУРИ РІВНЕНЬКОЇ ОБЛАСТІ}

\author{
Слащук А. М. \\ кандидат географічних наук, \\ доцент кафедри економічної та сочіальної географії \\ Волинський національний університет імені Лесі Украӥнки \\ Бернадська Г. О. \\ аспірантка кафедри економічної та сочуіальної географії \\ Волинський національний університет імені Лесі Украӥнки \\ м. Луцькк, Украӥна
}

Транспортний комплекс - один 3 найважливіших складових туристичної інфраструктури кожного регіону. Він включає автомобільне, залізничне, повітряне сполучення та міський електротранспорт. 
Залізничний транспорт України є провідною галуззю в дорожньотранспортному комплексі країни, який забезпечує $82 \%$ вантажних i майже 50\% пасажирських перевезень, що здійснюються всіма видами транспорту. Експлуатаційна мережа залізниць України складає майже 22 тис. км, з яких 45\% електрифіковано [4].

В даній роботі ми охарактеризуємо функціонування залізничного транспорту Рівненської області як складової туристичної інфраструктури, виділимо основні проблеми та перспективи.

Рівненська область розташована на північному заході Україні. Межує 3 Берестейською та Гомельською областями Білорусі, Житомирською, Хмельницькою, Тернопільською, Львівською та Волинською областями.

Область має вдале територіально-географічне розташування, яку перетинають такі транспортні коридори:

- Критський транспортний коридор № 3 (Краківець - Львів - Рівне - Житомир - Київ);

- Критський транспортний коридор № 5 (Косини - Чоп - Стрий Львів - Рівне - Сарни - Мінськ);

- Європа - Азія (Краківець - Львів - Рівне - Житомир - Київ Полтава - Харків - Дебальцеве - Ізварине);

- Балтійське море - Чорне море (Ягодин - Ковель - Луцьк Тернопіль - Хмельницький - Вінниця - Умань - порти Чорного моря) [2, c. 32$]$.

Залізничний транспорт $є$ важливою складовою туристичної інфраструктури Рівненщини. Експлуатаційна довжина залізничних колій у межах Рівненської області становить 605,8 кілометра, 3 них електрифіковані

170 кілометрів $(28,1 \%$ загальної довжини). Найбільшими залізничними вузлами в області є Рівне, Здолбунів і Сарни. В 2019 р. залізничним транспортом було перевезено 2,8 млн. осіб, 3 них 2,2 мл. осіб скористалися приміським сполученням, 0,6 млн. - міжміським (далеке сполучення) [1, с. 276-284].

Найбільший обсяг пасажирських перевезень в регіоні забезпечується найкраще технічно обладнаними двоколісними електрифікованими лініями на ділянках Красне - Здолбунів - Рівне Клевань.

Найважливішими залізничними магістралями, що проходять територією регіону є: Київ-Ковель, Київ-Рівне, Ковель-Київ, Новоолексіївка-Ковель, Рівне-Миколаїв, Рівне-Шепетівка, РівнеУдрицьк.

На кордоні з Республікою Білорусь в Рівненській області працює 1 міжнародний пункт пропуску для залізничного сполучення 
«Удрицьк» та 1 пункт контролю митного поста «Сарни» на залізничній станції Сарни, які знаходяться в Сарненському районі [3].

Важливо відмітити, що у 2020-2021 pр. у зв'язку з пандемією COVID-19 пасажирські перевезення було обмежено. Через це кількість пасажирів, що скористалися залізничним транспортом значно скоротилася.

Привабливим туристичним об'єктом та, власне, i елементом туристичної інфраструктури $є$ вузькоколійна залізниця АнтонівкаЗарічне, що функціонує орієнтовно з 1895 року. Першочерговим завданням було вивезення деревини. Експлуатаційна довжина колій становить 105,8 км. Маршрут проходить між віддаленими селами, і $\epsilon$ чи не єдиним сполученням через відсутність автошляхів.

Дана вузькоколійка $\epsilon$ найдовшою діючою в Європі. Також унікальним є міст через річку Стир: це єдиний дерев'яний залізничний міст в Україні та найдовший дерев'яний залізничний міст в Свропі (довжина 153 м). 32010 року залізничне сполучення Антонівка-Зарічне $\epsilon$ центром етно-тур-фесту «Бурштиновий шлях». За перші два роки тут побували понад 16 тисяч туристів. Щороку сюди приїздить все більше мандрівників, серед них поляки, німці, чехи, голландці, канадці, американці та ін. Зважаючи на це, в області було реалізовано проєкт у сфері туризму «Поліський трамвай», в межах якого були створені нові об'єкти туристичної інфраструктури [2, с. 34].

Однак, у 2020 через введення суворих карантинних обмежень Акціонерне товариство «Українська залізниця» зупинила пасажирські маршрути. Пізніше, після пом'якшення обмежень, маршрут АнтонівкаЗарічне не відновили через збитковість. Місцеві жителі та активісти зверталися у відповідні органи із заявою відновити сполучення, проте станом на 2021 рік вузькоколійний шлях Антонівка-Зарічне не працює.

Отож, залізничний транспорт Рівненщини $є$ важливою складовою туристичної інфраструктури регіону. Проте ступінь використання знаходиться на низькому рівні. Це пов'язано в першу чергу 3 незадовільним матеріально-технічним станом потягів, відміною багатьох рейсів та недостатньою популяризацією цього виду пересування.

Вузькоколійна залізниця Антонівка-Зарічне є найдовшою діючою залізницею в Європі, щороку приваблює багатьох туристів, а на даний момент взагалі не функціонує.

Перспективами функціонування залізничного транспорту Рівненщини є реставрація устаткування, введення нових маршрутів та відновлення курсування рейсу Антонівка-Зарічне як важливої туристичної дестинації. 


\title{
Література:
}

1. Мороз Ю. (за ред.) Статистичний щорічник Рівненської області за 2019 рік. Рівне: Головне управління статистики у Рівненській області, 2020. $393 \mathrm{c}$.

2. Стратегія економічного та соціального розвитку Рівненської області на період до 2027 року. Рівне : Обласна державна адміністрація, 2019. 160 с.

3. Державна прикордонна служба України. Перелік пунктів пропуску. URL: https://dpsu.gov.ua/ua/Perelik-punktiv-propusku?fbclid= IwAR1r2igX_cciwlP9qyf0XXUJLCtUDRzGf1fwF71fsHCMCn_Drkul2aVn Gr4 (дата звернення: 24.06.2021).

4. Міністерство інфраструктури України. Залізничний транспорт. URL: https://mtu.gov.ua/timeline/Zaliznichniy-transport.html (дата звернення: 24.06.2021).

DOI https://doi.org/10.30525/978-9934-26-111-4-41

\section{НЕБЕЗПЕКА ЗАБРУДНЕННЯ ПОВІТРЯ В ІСТОРИЧНОМУ ЦЕНТРІ ЧЕРНІВЦІВ}

\author{
Явкін В. Г. \\ кандидат географічних наук, \\ доцент кафедри географії та менеджменту туризму \\ Чернівецький наџіональний університет імені Юрія Федьковича \\ Круль Г. Я. \\ кандидат географічних наук, \\ дочент кафедри географії та менеджменту туризму \\ Чернівецький національний університет імені Юрія Федьковича \\ Брик С. Д. \\ кандидат географічних наук, \\ асистент кафедри географії та менеджменту туризму \\ Чернівецький начіональний університет імені Юрія Федьковича \\ м. Чернівиі, Україна
}

Історико-культурна частина м. Чернівців, яка активно забудовувалася в період австрійської влади наприкінці XIX - на початку XX століть, нині приваблює дедалі більше туристів 3 усіх куточків 